\title{
Transcranial Doppler Sonography Monitors Cerebral Blood Flow of Mannitol-Treated Patients with Acute Large Hemispheric Infarction
}

\author{
Transkranial Doppler Sonografi Akut Genis Hemisferik Infarktüs \\ Nedeniyle Mannitol Tedavisi Gören Hastalarda Serebral Kan Akışını \\ Monitörize Eder
}

\author{
Quanlu WANG*, Hong YE*, Yingying SU \\ Capital Medical University, Xuan Wu Hospital, Department of Neurology, Beijing, China \\ 'Quanlu Wang and Hong Ye contributed equally.
}

Corresponding Author: Yingying SU / E-mail: ying_yings200@163.com

\begin{abstract}
AIM: To evaluate the effect of mannitol at different doses $(125 \mathrm{ml}$ and $250 \mathrm{ml}$ ) by transcranial Doppler (TCD) sonography in patients with acute large hemispheric infarction.

MATERIAL and METHODS: 33 patients with acute large hemispheric infarction were enrolled, and the systolic peak velocity (Vs), end of diastolic velocity $(\mathrm{Vd})$, mean velocity $(\mathrm{Vm})$, pulsitility index $(\mathrm{PI})$ and percentage rate $(\mathrm{PR})$ of bilateral middle cerebral arteries were determined. RESULTS: (1) The bilateral Vs, Vd and Vm improved significantly from 30 to $120 \mathrm{~min}$ after $125-\mathrm{ml}$ mannitol infusion. The PI in the affected hemisphere decreased significantly at $30 \mathrm{~min}$. The improvement of $\mathrm{Vs} \%, \mathrm{Vd} \%, \mathrm{Vm} \%$ and $\mathrm{PI} \%$ in the affected hemisphere was more evident than in the unaffected hemisphere. (2) Bilateral Vs, Vd and Vm improved significantly from 30 to 90 min after 250-ml mannitol infusion. Bilateral PI decreased significantly from 30 to $60 \mathrm{~min}$. The improvement in $\mathrm{Vs} \%$, $\mathrm{Vd} \%$ and $\mathrm{Vm} \%$ in the unaffected hemisphere was more obvious than that in the affected hemisphere.

CONCLUSION: Single 125-ml mannitol infusion may significantly improve cerebral blood flow and decrease intracranial pressure, and single 250-ml mannitol infusion may markedly decrease the intracranial pressure in the affected hemisphere of patient with acute large cerebral infarction.
\end{abstract}

KEYWORDS: Mannitol, Sonography, Hemispheric infarction, Transcranial Doppler

öz

AMAÇ: Akut geniş hemisferik infarktüsü olan hastalarda farklı mannitol dozlarının (125 ml ve $250 \mathrm{ml}$ ) etkisini transkranial Doppler (TCD) sonografisi ile değerlendirmek.

YÖNTEM ve GEREÇLER: Akut geniş hemisferik infarktüsü olan 33 hasta kaydedildi ve bilateral orta serebral arterlerin sistolik pik hızı (Vs), diyastol sonu hızı (Vd), ortalama hız (Vm), pulsatilite indeksi (PI) ve yüzde oranı (PR) belirlendi.

BULGULAR: (1) Bilateral Vs, Vd and Vm $125 \mathrm{ml}$ mannitol infüzyonundan sonra 30 dakikadan 120 dakikaya önemli ölçüde düzeldi. Etkilenen hemisferdeki PI 30. dakikada önemli ölçüde azaldı. Etkilenen hemisferdeki \%Vs, \%Vd, \%Vm ve \%PI'nin düzelmesi etkilenmeyen hemisferdekinden daha belirgindi. (2) Bilateral Vs, Vd ve Vm, $250 \mathrm{ml}$ mannitol infüzyonundan sonra 30 dakikadan 90 dakikaya kadar önemli ölçüde düzeldi. Bilateral PI 30 dakikadan 60 dakikaya kadar önemli ölçüde azaldı. Etkilenmeyen hemisferdeki \%Vs, \%Vd ve \%Vm'nin düzelmesi etkilenen hemisferdekinden daha belirgindi.

SONUÇ: Tek bir $125 \mathrm{ml}$ mannitol infüzyonu serebral kan akışını önemli ölçüde arttırabilir ve serebral basıncını düşürebilirken, tek bir $250 \mathrm{ml}$ mannitol infüzyonu akut geniş hemisferik infarktüsü olan hastalarda etkilenen hemisferdeki intrakranial basıncı belirgin şekilde düşürebilir.

ANAHTAR SÖZCÜKLER: Mannitol, Sonografi, Hemisferik infarktüs, Transkranial Doppler

\section{INTRODUCTION}

Acute large hemispheric infarction usually causes serious brain edema leading to increase in intracranial pressure (ICP), decrease in cerebral perfusion pressure (CPP) and worsening brain ischemia. Experiments and clinical trials have shown that mannitol can attenuate the brain edema, decrease the ICP, and improve the CPP $(6,9,11)$. Mannitol has been widely used in the treatment of cerebral infarction as an osmotic agent. However, the therapeutic effect of mannitol may be compromised when the blood brain barrier is incomplete. 
Mannitol preferentially shrinks the non-infarcted brain causing the worsening of the shift of middle line. Currently, there is controversy on the application of mannitol in the treatment of cerebral infarction due to lack of evidence. To date, the changes in cerebral blood flow (CBF) and ICP after mannitol infusion are still poorly understood. The present study aimed to evaluate the effect of mannitol at different doses ( $125 \mathrm{ml}$ vs $250 \mathrm{ml}$ ) on the CBF and ICP in patients with acute large hemispheric infarction.

\section{SUBJECTS and METHODS}

A total of 33 patients with acute large hemispheric infarction were enrolled from the Department of Neurology in Xuanwu Hospital of Capital Medical University. This study was approved by the Ethical Committee of Xuanwu hospital, and written informed consent was obtained from patient's relatives.

Patients were recruited if they had CT or MRI-proven large hemispheric infarction, were admitted within 7 days of onset, were aged 40-85 years, weighed $50-80 \mathrm{~kg}$ and had a Glasgow coma scale score of 3-12. The large hemispheric infarction was confirmed when the infarction involved the areas supplied by two or three branches of middle cerebral artery or involved the areas supplied by middle cerebral artery and anterior cerebral artery (1). Patients were excluded if they had a history of carotid stenosis, severely functional disorders of the heart (blood pressure $<90 / 60 \mathrm{mmHg})$, lung $\left(\mathrm{PaO}_{2}<60 \mathrm{mmHg}\right.$ or $\mathrm{PaCO}_{2}>50 \mathrm{mmHg}$ ), and kidney (blood creatinine $>177 \mu \mathrm{mol} / \mathrm{L}$ ), or deficient acoustic window.

All the patients underwent neurological evaluation. Consciousness was evaluated with the Glasgow Coma Scale. The detection of blood pressure (BP), heart ratio (HR), pulse oxygen saturation $\left(\mathrm{SpO}_{2}\right)$ and haematocrit $(\mathrm{HCT})$ as well as blood gas analysis was performed.

All patients received an intravenous bolus infusion of $125 \mathrm{ml}$ of $20 \%$ mannitol within $15 \mathrm{~min}$. Six hours later, they received intravenous bolus infusion of $250 \mathrm{ml}$ of $20 \%$ mannitol within $30 \mathrm{~min}$. In the six hours before the test any osmotic agent was not used.

A 2-MHz pulse-wave Doppler probe placed on the temporal window was connected to a TCD instrument to measure the systolic peak velocity (Vs), end of diastolic velocity (Vd), mean velocity $(\mathrm{Vm})$ of bilateral middle cerebral arteries before and at different time points after mannitol infusion $(0,30,60,90$, 120 and $240 \mathrm{~min}$ ). The values were recorded when the above parameters reached a maximal level. The pulsatility index (PI) $[(\mathrm{Vs}-\mathrm{Vd}) / \mathrm{Vm}]$ was then calculated. The percentage [(Tn-T0)/ T0 $\times 100 \%$ ] was calculated to reflect the changes, where T0 and $\mathrm{Tn}$ refer to variables before and after mannitol infusion. Systolic and diastolic blood pressures were recorded the time of TCD sonography.

Analysis was performed using the SPSS version 12.0 for Windows. Continuous variables were described as median \pm standard deviation (SD). The analysis of variance was applied to compare the $\mathrm{Vm}$ and $\mathrm{PI}$ at different time points. The paired $t$ test was used to compare the bilateral $\mathrm{Vm}$ and PI. A value of $\mathrm{P}<0.05$ was considered statistically significant.

\section{RESULTS}

The characteristics and variables at the pre-designed time points are shown in Table I. MABP, $\mathrm{HR}$ and $\mathrm{SpO}_{2}$ remained unchanged during the study period (data not shown).

TCD variables are shown in Table II and Table III. After 125$\mathrm{ml}$ mannitol infusion, the bilateral Vm of MCA elevated significantly from $30 \mathrm{~min}$ to $120 \mathrm{~min}$, and reached a peak at 30 $\mathrm{min}$. The PI in the affected hemisphere decreased significantly at $30 \mathrm{~min}$. After 250-ml mannitol infusion, the Vm elevated markedly in the affected hemisphere from $30 \mathrm{~min}$ to $120 \mathrm{~min}$ and in the unaffected hemisphere from $30 \mathrm{~min}$ to $90 \mathrm{~min}$. The $\mathrm{Vm}$ reached a maximal level at $30 \mathrm{~min}$. The bilateral $\mathrm{PI}$ of MCA decreased dramatically from $30 \mathrm{~min}$ to $60 \mathrm{~min}$.

Percentage showed the change of $\mathrm{Vm}$ and PI straightly. Figure 1 and 2 are showing the tendencies in $\mathrm{Vm} \%$ and $\mathrm{PI} \%$. After $125-\mathrm{ml}$ mannitol infusion, the $\mathrm{Vm} \%$ elevated in the affected hemisphere from $30 \mathrm{~min}$ to $120 \mathrm{~min}$ and in the unaffected hemisphere from $30 \mathrm{~min}$ to $90 \mathrm{~min}$. The $\mathrm{Vm} \%$ reached a peak earlier in the affected hemisphere $(30 \mathrm{~min})$ than in the unaffected hemisphere (60 min). After 250-ml mannitol infusion, the bilateral Vm\% of MCA elevated from 30 to $60 \mathrm{~min}$ and reached a maximal level at $30 \mathrm{~min}$. The PI\% decreased from $30 \mathrm{~min}$ to $90 \mathrm{~min}$ after $125-\mathrm{ml}$ mannitol infusion and from $30 \mathrm{~min}$ to $240 \mathrm{~min}$ after $250-\mathrm{ml}$ mannitol infusion. The $\mathrm{PI} \%$ peaked at $30 \mathrm{~min}$ in the affected hemisphere and at $60 \mathrm{~min}$ in the unaffected hemisphere. The $\mathrm{Vm} \%$ and $\mathrm{PI} \%$ in affected and unaffected hemispheres were comparable.

\section{DISCUSSION}

Our results showed that the CBF velocity in bilateral MCAs elevated quickly after $125-\mathrm{ml}$ mannitol infusion, and could last $240 \mathrm{~min}$. Although there was no difference in the CBF

Table I: Demographics and Variables at T0 (mean \pm SD; $\mathrm{n}=33$ )

\begin{tabular}{l|c|c|}
\hline Demographics and Variables at T0 & \multicolumn{2}{|c|}{$65 \pm 13$} \\
\hline Age, yrs & & M: $27, \mathrm{~F}: 6$ \\
\hline Sex, $\mathrm{n}$ & & 20 \\
\hline Area of infarction & two branches of MCA & 11 \\
& three branches of MCA & 2 \\
\hline GCS score & MCA and ACA & $12 \pm 2$ \\
\hline HCT, \% & & $40.75 \pm 7.90$ \\
\hline $\begin{array}{l}\text { Blood gas } \\
\text { analysis }\end{array}$ & $\mathrm{PH}$ & $7.41 . \pm 0.05$ \\
\hline & $\mathrm{PaO}_{2}(\mathrm{mmHg})$ & $97.10 \pm 21.67$ \\
\hline MABP $(\mathrm{mmHg})$ & $\mathrm{PaCO}_{2}(\mathrm{mmHg})$ & $36.77 \pm 6.70$ \\
\hline
\end{tabular}

MCA: middle cerebral artery; ACA: anterior cerebral artery; GCS: Glasgow Coma Scale; HCT: haematocrit; MABP: mean arterial blood pressure. 
velocity between the affected hemisphere and unaffected hemisphere, the improvement in the CBF velocity in the affected hemisphere was more evident than in the unaffected hemisphere. CBF velocity in the affected CBF peaked earlier than in the unaffected CBF (30 min vs $60 \mathrm{~min}$ ). After 250 - $\mathrm{ml}$ mannitol infusion, the improvement in CBF velocity in the unaffected hemisphere was more obvious than in the affected hemisphere. CBF velocity reached a peak at $30 \mathrm{~min}$ in bilateral MCAs. Intravenous mannitol infusion can increase the plasma osmotic pressure $(315-320 \mathrm{mOsm} / \mathrm{L})$, elevate the

Table II: TCD Variables and Percentage in Variables Before and After 125-ml Mannitol Infusion

\begin{tabular}{|l|c|c|c|c|c|c|c|}
\hline Hemisphere & & $0 \mathrm{~min}$ & $30 \mathrm{~min}$ & $60 \mathrm{~min}$ & $90 \mathrm{~min}$ & $120 \mathrm{~min}$ & $240 \mathrm{~min}$ \\
\hline Affected & $V \mathrm{Vm}(\mathrm{cm} / \mathrm{s})$ & $54.73 \pm 32.27$ & $63.47 \pm 31.63^{\mathrm{b}}$ & $60.94 \pm 31.98^{\mathrm{b}}$ & $59.64 \pm 32.75^{\mathrm{b}}$ & $61.23 \pm 31.07^{\mathrm{b}}$ & $59.62 \pm 27.24$ \\
& $\mathrm{Vm} \%$ & 0 & $19.72 \pm 13.49$ & $14.47 \pm 17.28$ & $11.81 \pm 14.03$ & $11.42 \pm 13.99$ & $7.67 \pm 13.99$ \\
\hline & $\mathrm{PI}$ & $0.91 \pm 0.23$ & $0.87 \pm 0.20^{\mathrm{a}}$ & $0.89 \pm 0.23$ & $0.88 \pm 0.19$ & $0.92 \pm 0.23$ & $0.93 \pm 0.24$ \\
\hline \multirow{3}{*}{$\begin{array}{l}\text { Unaffected } \\
\text { MCA }\end{array}$} & $\mathrm{Pl} \%$ & 0 & $-4.13 \pm 12.29$ & $-2.09 \pm 12.93$ & $-1.75 \pm 13.05$ & $1.81 \pm 12.01$ & $3.37 \pm 15.12$ \\
\hline & $\mathrm{Vm}$ & $64.20 \pm 28.97$ & $73.10 \pm 34.57^{\mathrm{b}}$ & $72.83 \pm 31.74^{\mathrm{b}}$ & $71.11 \pm 33.02^{\mathrm{b}}$ & $67.77 \pm 28.89^{\mathrm{a}}$ & $68.24 \pm 30.78$ \\
& $\mathrm{Vm} \%$ & 0 & $13.09 \pm 13.88$ & $14.33 \pm 11.60$ & $11.33 \pm 14.27$ & $6.81 \pm 15.49$ & $6.45 \pm 19.69$ \\
\hline & $\mathrm{Pl}$ & $1.03 \pm 0.18$ & $1.01 \pm 0.18$ & $1.00 \pm 0.22$ & $1.01 \pm 0.23$ & $1.02 \pm 0.21$ & $1.06 \pm 0.22$ \\
\hline & $\mathrm{Pl} \%$ & 0 & $-2.27 \pm 9.61$ & $-3.67 \pm 13.19$ & $-2.55 \pm 11.13$ & $-0.53 \pm 13.96$ & $2.42 \pm 12.28$ \\
\hline
\end{tabular}

${ }^{a} P<0.05$ vs $0 \mathrm{~min},{ }^{b} P<0.01$ vs $0 \mathrm{~min}$.

Table III: TCD Variables and Percentage in Variables Before and After 250-ml Mannitol Infusion

\begin{tabular}{|l|c|c|c|c|c|c|c|}
\hline Hemisphere & & $0 \mathrm{~min}$ & $30 \mathrm{~min}$ & $60 \mathrm{~min}$ & $90 \mathrm{~min}$ & $120 \mathrm{~min}$ & $240 \mathrm{~min}$ \\
\hline Affected & $\mathrm{Vm}(\mathrm{cm} / \mathrm{s})$ & $58.16 \pm 20.47$ & $65.95 \pm 24.34^{\mathrm{b}}$ & $62.51 \pm 20.83^{\mathrm{b}}$ & $61.17 \pm 21.31^{\mathrm{a}}$ & $61.22 \pm 20.30^{\mathrm{a}}$ & $58.00 \pm 20.55$ \\
& $\mathrm{Vm} \%$ & 0 & $13.86 \pm 15.83$ & $8.93 \pm 12.09$ & $6.00 \pm 13.10$ & $7.07 \pm 14.73$ & $0.46 \pm 11.65$ \\
\hline & $\mathrm{Pl}$ & $0.95 \pm 0.25$ & $0.87 \pm 0.19^{\mathrm{b}}$ & $0.88 \pm 0.20^{\mathrm{b}}$ & $0.92 \pm 0.24$ & $0.93 \pm 0.25$ & $0.93 \pm 0.25$ \\
\hline \multirow{3}{*}{$\begin{array}{l}\text { Unaffected } \\
\text { MCA }\end{array}$} & $\mathrm{Pl} \%$ & 0 & $-7.04 \pm 11.20$ & $-6.04 \pm 11.01$ & $-2.71 \pm 9.32$ & $-1.93 \pm 11.48$ & $-1.39 \pm 14.06$ \\
& $\mathrm{Vm}$ & $68.44 \pm 30.92$ & $80.69 \pm 37.44^{\mathrm{b}}$ & $77.32 \pm 37.49^{\mathrm{b}}$ & $74.38 \pm 35.63^{\mathrm{b}}$ & $71.80 \pm 35.99$ & $70.86 \pm 36.24$ \\
& $\mathrm{Vm} \%$ & 0 & $18.79 \pm 14.77$ & $12.50 \pm 14.64$ & $9.21 \pm 16.24$ & $4.89 \pm 17.65$ & $2.86 \pm 11.92$ \\
\hline & $\mathrm{PI}$ & $1.04 \pm 0.22$ & $0.99 \pm 0.21^{\mathrm{a}}$ & $0.96 \pm 0.23^{\mathrm{a}}$ & $0.99 \pm 0.22$ & $1.03 \pm 0.25$ & $1.06 \pm 0.23$ \\
\hline & $\mathrm{Pl} \%$ & 0 & $-4.00 \pm 11.07$ & $-6.36 \pm 14.34$ & $-3.57 \pm 13.20$ & $-1.04 \pm 10.85$ & $2.25 \pm 10.76$ \\
\hline
\end{tabular}

${ }^{a} P<0.05$ vs $0 \mathrm{~min},{ }^{b} P<0.01$ vs $0 \mathrm{~min}$.

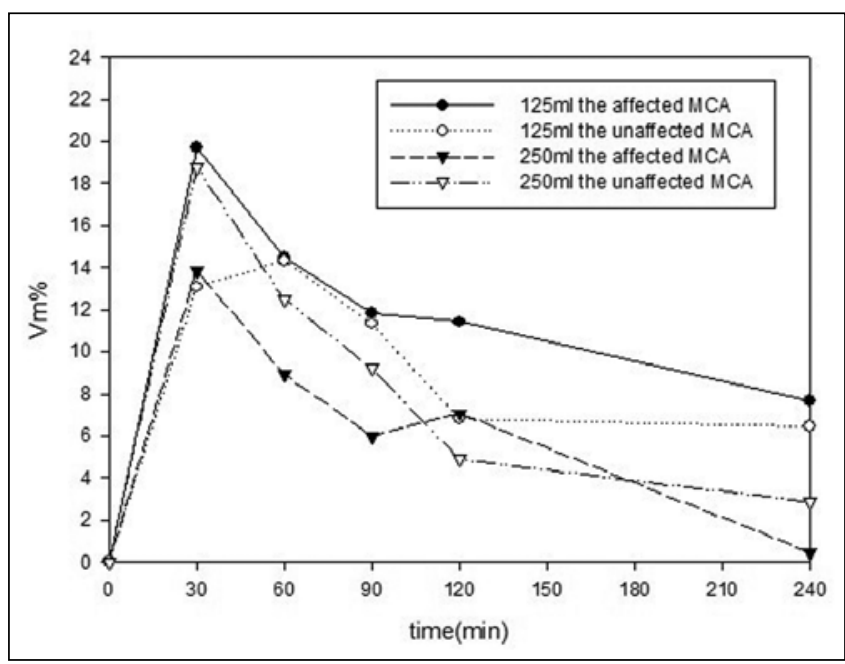

Figure 1: Change in Vm\% (mean) within 240 min after mannitol infusion.

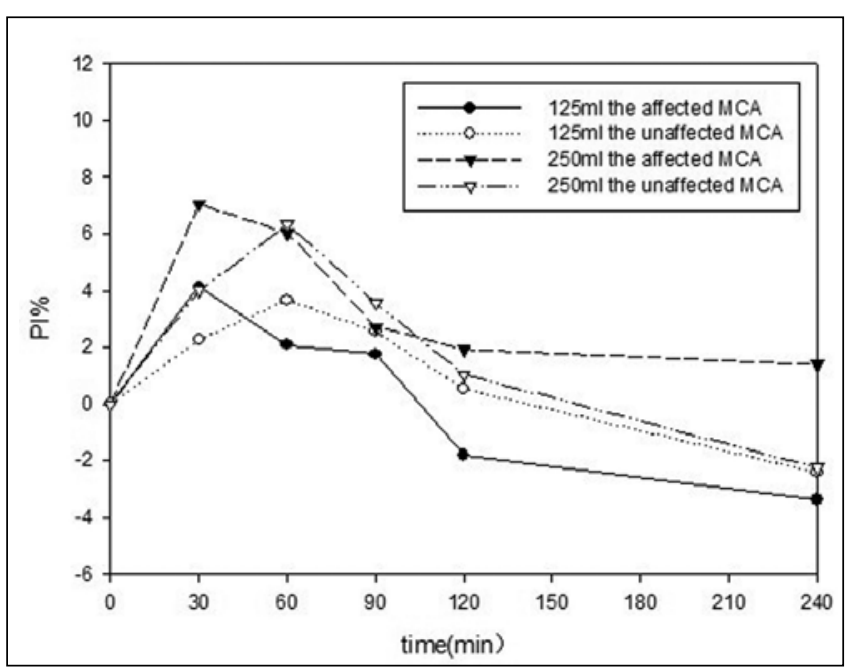

Figure 2: Change in PI\% (mean) within 240 min after mannitol infusion. 
blood volume, decrease the blood viscosity, enhance the erythrocyte deformability and increase the cerebral blood volume $(2,8,12)$. Vm of MCA reflects the CBF. Our findings implied that mannitol could improve the CBF which is important for the improvement of low CPP secondary to acute large hemispheric infarction. When compared with infusion of $250 \mathrm{ml}$ of mannitol, $125-\mathrm{ml}$ mannitol infusion was more beneficial for the improvement of $\mathrm{CBF}$, especially in the affected hemisphere. Thus, $125-\mathrm{ml}$ mannitol is suitable for single bolus infusion aiming to improve CBF.

Our findings showed that the PI of bilateral MCAs decreased from $30 \mathrm{~min}$ to $90 \mathrm{~min}$ after $125-\mathrm{ml}$ mannitol infusion and from $30 \mathrm{~min}$ to $120 \mathrm{~min}$ after $250-\mathrm{ml}$ mannitol infusion. After 250-ml mannitol infusion, the decrease in Pl in the affected hemisphere was more evident than in the unaffected hemisphere.

Studies have proved the correlation ICP and PI $(10,13)$. TCD has been widely used as a non-invasive technique to monitor ICP if the invasive monitoring is difficult or harmful. Our results confirmed that $250-\mathrm{ml}$ mannitol was more powerful to decrease ICP, especially in the affected hemisphere. It has been confirmed in animal experiments that repeated mannitol infusions resulted in a dose-dependent increase in plasma osmolality and a dose-dependent decrease in the percent $\mathrm{H}_{2} \mathrm{O}$ of the ischemic MCA cortex and ipsilateral hemisphere (2). Acute large hemispheric infarction often leads to malignant brain edema resulting in increase in ICP or even acute herniation of the brain (3). Our results showed that PI decreased after mannitol infusion, especially in the affected hemisphere after $250-\mathrm{ml}$ mannitol infusion. Some studies had shown the adverse effects of mannitol infusion following cerebral infarction. Their explanations are that mannitol can leak from vessels to the brain though the incomplete blood brain barrier leading to the increase in osmotic pressure and decrease the dehydrolysis. In contrast, blood brain barrier of the unaffected hemisphere is complete, and thus dehydrolysis of mannitol is more effective than in the affected hemisphere. The asymmetry of ICP in bilateral hemispheres increase the risk for middle line shift $(5,7,9,14)$. Our results were not consistent with above findings. Decrease in $\mathrm{PI}$ in bilateral MCAs reflects the decrease in ICP. The decrease in PI in the affected hemisphere was greater than in the unaffected hemisphere. Thus, middle line shift was unable to occur after infusion of mannitol at high dose (4). For patients with large hemispheric infarction, both $125-\mathrm{ml}$ and $250-\mathrm{ml}$ mannitol infusion is feasible. The $250-\mathrm{ml}$ mannitol fo bolus infusion is a better choice for patients with malignancy brain edema and signs of brain hernia.
Taken together, a single mannitol (both $125 \mathrm{ml}$ and $250 \mathrm{ml}$ ) infusion can improve CBF and decrease ICP. In the selection of dose of mannitol, the severity of large hemispheric infarction should be taken into accounted.

\section{REFERENCES}

1. Aiyagari $\mathrm{V}$, Diringer $\mathrm{MN}$ : Management of large hemispheric strokes in the neurological intensive care unit. Neurologist 8:152-162, 2002

2. Ambühl PM, Ballmer PE, Krähenbühl S, Krapf R: Quantification and predictors of plasma volume expansion from mannitol treatment. Intensive Care Med 23:1159-1164, 1997

3. Dennis LJ, Mayer SA: Diagnosis and management of increased intracranial pressure. Neurol-India 49: 37-50, 2001

4. Henderson G V: Management of massive cerebral infarct. Curr Neurol Neurosci Rep 4: 497 - 504, 2004

5. Hofmeijer J, van der Worp HB, Kappelle LJ: Treatment of space-occupying cerebral infarction. Criti Care Med 31:617625,2003

6. Lv XP, Su YY: Changes in cerebral blood flow in patients with acute cerebral stroke before and after mannitol infusion. Chin J Cerebrovasc Dis 3:118-122, 2006

7. Manno EM, Adams RE, Derdeyn CP, Powers WJ, Diringer $\mathrm{MN}$ : The effects of mannitol on cerebral edema after large hemispheric cerebral infarct. Neurology 52:583-587, 1999

8. Paczynski RP:Osmotherapy: Basic concepts and controversies. Crit Care Clin 13:105-129, 1997

9. Paczynski RP, He YY, Diringer MN, Hsu CY: Multiple-dose mannitol reduces brain water content in a rat model of cortical infarction. J Stroke 28:1437-1444, 1997

10. Rainov NG, Weise JB, Burkert W: Transcranial Doppler sonography in adult hydrocephalic patient. Neurosurg Rev 23:34-38, 2000

11. Schwarz S, Schwab S, Bertram M, Aschoff A, Hacke W: Effects of hypertonic saline hydroxyethyl starch solution and mannitol in patients with increased intracranial pressure after stroke. J Stroke 29:1550-1555, 1998

12. Steiner $T$, Ringleb $P$, Hacke $W$ : Treatment options for large hemispheric stroke. Neurology 57(5 Suppl 2):61-68, 2001

13. Ungersböck K, Tenckhoff D, Heimann A, Wagner W, Kempski OS: Transcranial Doppler and cortical microcirculation at increased intracranial pressure and during the Cushing response: An experimental study on rabbits. Neurosurgery 36:147-157, 1995

14. Videen TO, Zazulia AR, Manno EM, Derdeyn CP, Adams RE, Diringer MN, Powers WJ: Mannitol bolus preferentially shrinks non-infarcted brain in patients with ischemic stroke. Neurology 57:2120-2122, 2001 